\title{
Faculty Retention in Higher Education
}

\author{
Tariq Rahim Soomro ${ }^{1} \&$ Reyaz Ahmad ${ }^{1}$ \\ ${ }^{1}$ College of Engineering \& IT, Al Ain University of Science \& Technology, Al Ain, UAE \\ Correspondence: Tariq Rahim Soomro, College of Engineering \& IT, Al Ain University of Science \& Technology, \\ Al Ain, United Arab Emirates. Tel: 971-3-702-4883. E-mail: tariq.soomro@aau.ac.ae
}

Received: April 12, 2013

Accepted: May 5, 2013

Online Published: May 7, 2013

doi:10.5430/ijhe.v2n2p147

URL: http://dx.doi.org/10.5430/ijhe.v2n2p147

\begin{abstract}
Criteria for retaining or firing a highly qualified faculty in higher education in many cases are vague and unclear. This situation is neither a comfortable, nor a healthy, both for the faculty and the administration. Stakeholders have enough reason to blame each other in the absence of transparent mechanism. This paper proposes a transparent point system for both faculty and higher education administration based on three most important categories - Teaching $(\mathrm{T})$, Research (R), and community Service (S). This proposed transparent point system will present solution to resolve confusion among stakeholders. Faculty based on this transparent proposed point system may perform well and administration based on this proposed point system may decide to retain the faculty.
\end{abstract}

Keywords: Higher education, Faculty retention, Teaching, Research, Community service

\section{Introduction}

\subsection{Introduce the Problem}

Higher education is meant relatively different for different stakeholders, for example, internal and external stakeholders (Soomro et al., 2012) (Becket et al., 2008) (Rana et al., 2009). Internal stakeholders here means students, faculty, administrative staff etc. and external stakeholders here means parents, ministry of higher education or equivalent authrities, educational suppliers etc. In the past these stakeholders were concerned about the nature of programs and other factors, such as, fees and location of the higher educational institutions. The current concern of the stakeholders is on facility, faculty and locality (Soomro et al., 2012). The purpose of this paper is to reten faculty and that's why we will only focuses on "faculty" rather than facility and locality. Quality faculty is an important asset for any institution offering higher education. Attracting and retening quality faculty is very important to educational institutions as low faculty retention rate might create both monetary and academic consequences (Rensselaer Polytechnic Institute, 2012). Monetary consequences include a lost return on a previous investment, e.g. the cost of recruiting a replacement faculty, and the time of other faculty diverted to the hiring process. According to the American Management Association, the cost of replacing an employee is bigger and can be calculated predictably at $30 \%$ of an employee's annual salary (Lavania et al., 2011). Quality factuly on the one hand is moving from one school to another for a better packages and facilities, but on the other hand, has been removed or fired by administrations for known or unknown reasons. How administration can transparently keep quality faculty and fire unwanted unqualified faculty is also a major challenge. This paper is written keeping in view of this problem and will suggest a transparent methodology to retain qualified quality faculty. Section 2 will explain the categories proposed methodology with examples (below average, average, and above average). Section 3 will conclude and discuss possible future work.

\section{Proposed Methodology}

According to (Soomro et al., 2012) (Penn State Altoona, 2013) full time faculty members in Universities are supposed to work in three different dimensions (3D) as below:

- Teaching (T),

- Research (R) and

- community Services (S)

Teaching (T) is an extremely important duty to discharge for full time faculty and to measure or grade its outcomes two different tools are adopted as bellow: 
- Assessment of the faculty member's teaching performance by the students through a Questionnaire in a five-point scale (1-5), where 1 stands for strongly disagreed, whereas 5 stands for strongly agreed, and

- Assessment by the Supervisor (Dean or Head of Department), again in through Questionnaire in a five-point scale (1-5), where 1 stands for strongly disagreed, whereas 5 stands for strongly agreed

Research ( $\mathrm{R}$ ) is another important responsibility of faculty member of higher education. They are supposed to be actively involved in the research work by publishing in the Journals and participating in International conferences. In this way, faculty members, not only, can improve their teaching quality, but also can update themselves as well as the students about the recent trends and research interest of the intellectuals of the world in the subject, which he/she is assigned to teach.

Community Service (S) is vital for all faculty members, because this way they can engage themselves with local and International community directly or indirectly.

Authors are proposing below the transparent formulae (point system: as table 1), which will simplify the retention criteria of qualified quality faculty in higher education. At the same time authors are convinced that some Universities might differ with this system of gradation only due to their local issues and consideration.

Table 1. Categories and their points (Proposed Point System)

\begin{tabular}{lc}
\hline Categories & Points \\
\hline Teaching (T) & 60 \\
Research (R) & 25 \\
Community Service (S) & 15 \\
Total & 100 \\
\hline
\end{tabular}

\subsection{Teaching}

Teaching is irreplaceable (TNTP, 2012), important (Michael et al., 2005) and main factor to reten faculty. It is proposed to allocate a total of 60 points for teaching to be divided into two sub-categories:

- 50 points for the student's evaluation of the courses faculty is teaching and

- 10 points for the overall assessment by the supervisor (Dean or Head of Department)

Usually assessment of faculty starts in almost all the Universities in each semester's 12th week by asking the students to assess faculty through the questionnaire in five point scale ranging from 1 to 5 in different categories. 1 here means strongly disagreed and 5 here means strongly agreed. Similarly at the end of each semester faculty supervisor (e.g. Dean or Head of Department) is supposed to write an assessment for the faculty again in the range from 1 to 5 . Again 1 here means strongly disagreed and 5 here means strongly agreed. Points gain by the faculty members from both the students and Dean or Head of Department are shown in table 2 below: (example of below average, average and above average)

Table 2. Teaching categories points (Examples)

\begin{tabular}{lcccc}
\hline Teaching (T) Categories & Points & $\begin{array}{c}\text { Bellow Average } \\
\text { (Example) }\end{array}$ & $\begin{array}{c}\text { Average } \\
\text { (Example) }\end{array}$ & $\begin{array}{c}\text { Above Average } \\
\text { (Example) }\end{array}$ \\
\hline Assessment by Students & 50 & $1.5=15$ & $2.5=25$ & $4.5=45$ \\
Assessment by Supervisor & 10 & $1.5=3$ & $2.5=5$ & $4.5=9$ \\
Total & 60 & 18 & 30 & 54 \\
\hline
\end{tabular}

2.2 Research

It is proposed to allocate a total of 25 points for research activities undertaken by the faculty members in different categories, e.g. writing a book, or writing a research paper in an International Journal or a conference. The proposed distribution of Research $(\mathrm{R})$ points are shown in table 3 below: 
Table 3. Research cateogory points (Examples)

\begin{tabular}{lcccc}
\hline Research (R) Categories & Points & $\begin{array}{c}\text { Bellow Average } \\
\text { (Example) }\end{array}$ & $\begin{array}{c}\text { Average } \\
\text { (Example) }\end{array}$ & $\begin{array}{c}\text { Above Average } \\
\text { (Example) }\end{array}$ \\
\hline $\begin{array}{l}\text { Publication of International } \\
\text { Book }\end{array}$ & 20 & - & - & - \\
$\begin{array}{l}\text { Publication of Local Book } \\
\text { Publication of Chapter in an }\end{array}$ & 15 & - & - & - \\
$\begin{array}{l}\text { International / Local Book } \\
\text { Research Paper in Journal }\end{array}$ & 10 & - & - & - \\
$\begin{array}{l}\text { with Impact Factor } \\
\text { Research Paper in Journal } \\
\text { with ISI indexed (without }\end{array}$ & 13 & - & - & - \\
$\begin{array}{l}\text { Impact Factor) } \\
\text { Research Paper in Journal } \\
\text { with other International }\end{array}$ & 10 & - & $1 \times 13=13$ & $2 \times 10=20$ \\
$\begin{array}{l}\text { Indexed } \\
\text { Research Paper in }\end{array}$ & 8 & - & - & $1 \times 8=8$ \\
$\begin{array}{l}\text { International Conference } \\
\text { Research Paper in Local } \\
\text { Conference } \\
\text { Total }\end{array}$ & 5 & $1 \times 8=8$ & - & - \\
\hline
\end{tabular}

It is important to note that if faculty publishes several papers or more than one book, for example, then he/she may score points more than the maximum allocated 25 points for the research category, but he/she will be restricted with 25 points only as this is the maximum points that a particular faculty may score in this category. It is being mentioned again that the points distributed in research categories are just a proposal, institutions has right to modify it if it doesn't suit to their requirements and administrative needs.

\subsection{Community Service}

It is proposed to allocate a total of 15 points for community services performed by faculty members in different categories as shown below in table 4:

Table 4. Community service category points (Examples)

\begin{tabular}{lcccc}
\hline $\begin{array}{l}\text { Community Service (S) } \\
\text { Categories }\end{array}$ & Points & $\begin{array}{c}\text { Bellow Average } \\
\text { (Example) }\end{array}$ & $\begin{array}{c}\text { Average } \\
\text { (Example) }\end{array}$ & $\begin{array}{c}\text { Above Average } \\
\text { (Example) }\end{array}$ \\
\hline $\begin{array}{l}\text { International Consultancy } \\
\text { Local Consultancy }\end{array}$ & 15 & - & - & - \\
$\begin{array}{l}\text { International Review of } \\
\text { Journal / Conference / Book }\end{array}$ & 13 & - & - & - \\
$\begin{array}{l}\text { Local Review of Journal / } \\
\text { Conference / Book }\end{array}$ & 8 & - & - & $1 \times 10=10$ \\
$\begin{array}{l}\text { Organization of Conference } \\
\text { Workshop etc. }\end{array}$ & 7 & - & - & - \\
$\begin{array}{l}\text { Presenting the Seminar / } \\
\text { Workshop etc. }\end{array}$ & 7 & - & $1 \times 7=7$ & $1 \times 7=7$ \\
$\begin{array}{l}\text { University Level Committee } \\
\text { Engagement } \\
\text { College / Department Level } \\
\text { Committee Engagement }\end{array}$ & 5 & - & - & - \\
Total & 3 & $1 \times 5=5$ & - & $1 \times 5=5$ \\
\hline
\end{tabular}

It is again important to note that if faculty member is involved in several community service activities his/her score will cross the maximum allocated 15 points for this category, but according to the proposed point system he/she is only eligible to get maximum of 15 points. The points in community service categories are just proposal and may be modified depending upon the need and requirements of individual University administration.

Note that we tabulated three examples here, called "below average", "average" and "above average". Point system 
can be calculated according to the performance of each and individual faculty in three main responsibilities, which are - teaching $(\mathrm{T})$, research $(\mathrm{R})$, and community service (S). For example, if a faculty member is below average then he/she received $18+8+5=31$ out of 100 points. It is now for the administration to decide not to retain him/her as the performance of the faculty is really very poor, whereas, if a faculty member is average and his/her points are $30+13+7=50$ out of 100 points. It is again at the discretion of the administration to decide, weather to retain the faculty or not? Here lies the role of University administration to fix the boundaries between the range of $40 \%$ to $50 \%$ points keeping in view the circumstances of the University, students etc. Again as an example, if a faculty member is above average his/her points are $54+25+15=94$ out of 100 points. It is obvious that the University administration should decide to retain the faculty. One again it is important to note that this proposed point system is an initial proposal; University administration might change this system according to situation of the University, faculty and students.

\section{Discussion and Future Work}

Authors proposed transparent point system for both the administration and faculty of higher education. Faculty has to fulfill its responsibilities in all three categories that are - teaching (T), research (R), and community service (S). Although this paper suggest hard and fast point system rules, but it should also be noted that the firing of the faculty create lots of other problems for administration, such as cost of hiring, non-availability of faculty on time etc., so the best way to deal with this situation is that, when a faculty fail quality-wise, with whatever the reason may be (teaching, research and/or community service), higher education administration should play an intelligent role to overcome these deficiencies, for example, if faculty is not performing reasonable in teaching then training sessions may be provided to the faculty to overcome teaching issues, which may occur due to new environment or student behavior etc. If faculty is not performing well in research activities, then administration may suggest and provide faculty the opportunity to participate in research oriented seminars and workshops and in the same way if faculty is not performing sound in community services, then administration may guide faculty, where, when and how faculty may involved in community engagement, of course with the help of seniors. The purpose of this paper is not to give reason for administration to fire the faculty, but to provide a chance to find out the weaknesses and the strength of the faculty members. Providing faculty necessary help and guidance to fix or find the solution of the areas of weaknesses and using their strength in proper manners. After adopting proposed point system, and collection of real data, percentage distribution among three categories it may be readjusted keeping in view, the ability and interest of the faculty, for example, towards community services are towards research, his/her abilities should be utilized appropriately and accurately.

\section{References}

Becket N. \& Brookes M. (2008). Quality Management Practice in Higher Education - What Quality are We Actually Enhancing?. Journal of Hospitality, Leisure, Sport and Tourism Education. 7(1), 40-54. http://dx.doi.org/10.3794/johlste.71.174

Lavania Dolly, Himanshu Sharma \& Nidhi Gupta. (2011). Faculty Recruitment and Retention: A Key for Managing Talent in Higher Education. International Journal of Enterprise Computing and Business Systems. Vol. 1, Issue 2, July 2011. [Online] Available: http://www.ijecbs.com/July2011/32.pdf

Michael B. Allen., Richarch Ingersoll \& Jeffrey kralik. (2005). Eight questions on teacher recruitment and retention: what does the research say? The Education Commission of the States (ECS), [Online] Available: http://www.ecs.org/html/educationissues/teachingquality/trrreport/home/TeacherRecruitmentRetention.pdf

Penn State Altoona. (2013). Faculty Workload Policy. [Online] Available: http://www.altoona.psu.edu/academic/docs/10WorkloadPolicy.pdf

Rana S. (2009). Quality Management in Higher Education - A Perspective. 2nd COMSATS International Business Research Conference. November 14, 2009, Lahore Pakistan. [Online] Available: http://www.ciitlahore.edu.pk/pl/abrc/Proceedings/All\%20papers/QM\%20IN\%20HIGHER\%20EDUCATION\%2 0(Saba\%20Rana).pdf

Rensselaer Polytechnic Institute. (2012). Faculty retention proves a major challenge for universities. ScienceDaily. 16 Feb., 2012. [Online] Available: http://www.sciencedaily.com/releases/2012/02/120216144240.htm

Soomro Tariq Rahim \& Reyaz Ahmad. (2012). Quality in Higher Education: United Arab Emirates Perspective. Higher Education Studies. Vol. 2, No. 4, December 2012. Canadian Center of Science and Education. DOI: 10.5539/hes.v2n4148. [Online] Available: http://www.ccsenet.org/journal/index.php/hes/article/view/22581

TNTP reimagine teaching. (2012), The Irreplaceables, Understanding the real retention crises in America's urban schools, [Online] Available: http://tntp.org/assets/documents/TNTP_Irreplaceables_2012.pdf 